\title{
Pronunciation Intelligibility of Nigerian Speakers of English
}

\author{
Fiyinfolu Olubunmi Idowu, \\ London Brunel Int'l College, Brunel University, \\ Uxbridge Middlesex, United Kingdom
}

Doi:10.19044/esj.2019.v15n20p101 URL:http://dx.doi.org/10.19044/esj.2019.v15n20p101

\begin{abstract}
The study examines the phonological intelligibility of Nigerian speakers of English. Specifically, it investigates the extent to which vowel quality in the speech of Nigerian Speakers of English affects their intelligibility to speakers from different contexts.100 evaluators, (international listeners made up of non-Nigerian speakers) transcribed six speech samples from six audio podcasts in which Nigerian speakers delivered speeches. The transcription of the different speech samples served to assess intelligibility at pronunciation level (specifically segmental features). Results revealed that using vowel realisations distinct from the central vowels [ $\Lambda$ ], [3:], and [ə] caused intelligibility problems for international listeners.
\end{abstract}

Keywords: English as a lingua franca, intelligibility, Nigerian English, pronunciation, teaching

\section{Introduction}

This study investigates the intelligibility of Nigerian speakers of English to international listeners (non-Nigerian speakers of English). It developed as a response to the changes in the role that English plays in the world today. In the past, the teaching of English to speakers of other languages was based on "native-speaker" norms usually British English in the form of Received Pronunciation and General American English. In other words, people studied English intending to interact with native English speakers, who were considered by all to be the owners of the language, "guardians of its standards, and arbiters of acceptable pedagogic norms" (Jenkins 2000:5). "Native-like" accent was a parameter and a goal regardless of the status of English as "second" or "foreign" language. To achieve their goal, it was considered important for these speakers of other languages to approximate as closely as possible to the native standard, particularly with regard to 
pronunciation (either Received Pronunciation (RP) or General American (GA).

However, in recent years, the goals of English language teaching and the notion of the native speaker (NS) as the norm provider are being questioned (Nero, 2006) as a result of the rise of English as an international language (EIL) and the reality that there are now more non-native speakers (NNSs) of English than native speakers (NSs) (Kachru \&Nelson 1996; Crystal, 2003; Kachru, 2005; Kirkpatrick, 2006; 2007b; Jenkins, 2007; Deterding, 2011).

In line with these changes, a number of scholars have called into question the issue of who owns the English language and consequently, who is allowed to set the standards against which use is to be established. Jenkins (2000) argues that no one denies the rights of "native speakers" to establish their own standards for use in interaction with other "native speakers" and even with "non-native speakers". However, the important question is: what forms or models would be appropriate for successful interaction among international L2 speakers. According to Jenkins, the view that "native speakers" do not own English as an international language (EIL) has been held for a long time. Graddol, for example, asserted in his book, the future of English, "Native speakers may feel the language "belongs" to them, but it will be those who speak English as a second language or foreign language who will determine its world future' (ibid:10). This position is expressed most emphatically by Widdowson (1994) who wrote:

'How English develops in the world is no business whatever of native speakers in England, the United States, or anywhere else. They have no say in the matter, no right to intervene or pass judgment. They are irrelevant. The fact that English is an international language means that no nation can have custody over it. To grant such custody of the language is necessarily to arrest its development and so undermine its international status. It is a matter of considerable pride and satisfaction for native speakers of English that their language is an international means of communication. But the point is that it is only international to the extent that it is not their language. It is not a possession which they lease out to others, while still retaining the freehold other people actually own it' (1994:385).

Given this reality of English, the concept of intelligibility has emerged as one of the goals or the most important criterion for English language teaching. In Trudgill's words, there is 'a greater fear that English is now used so widely around the world, and is in particular used by so many non-native speakers, that if we are not careful, and very vigilant, the language will quite rapidly break up into a series of increasingly mutually unintelligible dialects, and eventually into different languages (Trudgill 1998:29), much like the splitting 
up over time of Classical Latin into vernacular Romance languages (Rubdy and Saraceni 2006).

To ensure mutual intelligibility in diverse societies, Quirk (1990) maintains the need for a standard model of native English for international communication. To him, the point of reference is necessarily an L1 variety of English, and the standard for intelligible English pronunciation is set by L1 English listeners. This has set the stage for researchers of World Englishes (The term "World-Englishes" refers to the world's multiple varieties of English (Kirkpartick, 2007; Jenkins, 2009)), and English as a Lingua Franca (English as a Lingua Franca (ELF) refers to communication in English between speakers with different first languages including, possibly, NSs (Jenkins, 2007; Seidlhofer, 2005)) to make a case for which standards should be used to determine the intelligibility of English for international communication.

While an L1 English reference fits the research and teaching model for L1 English contexts of usage, scholars of WE and ELF contend that many L2 speakers of English today will not be interacting mainly with L1 English speakers. They assert that many L2 English users already speak their desired target English variety, such as Nigerian English and Indian English, even if it may not be an L1 variety of English. From the WE and ELF perspectives, L1 and L2 speakers of English are equally responsible for effective international communication, and research in L2 English contexts and English language teaching has been called upon to better reflect this new, more diverse global reality.

This current paper aims to contribute to this research by examining the pronunciation intelligibility of Nigerian speakers of English to both L1 and L2 listeners to help determine the priorities for pronunciation teaching of English in the international context. In the specific context of Nigeria, this research is important as statistics show that one out of every four Africans is a Nigerian (Adetula, 2013). For example, in 2017, the President of the Nigerian Medical Association (NMA) told New Telegraph that between 10,000 and 15,000 Nigerian doctors are now practising medicine outside the country (Adeyemi 2017). Nigerians are scattered all over the world: Saudi, U.S. UK, and the Soviet Union to mention but a few. Nigeria is the most populous black nation with approximately 167 million people (Adetula, 2013) and its size, natural resource endowment, economy, and influence in global affairs have continued to attract considerable scholarly and international companies' attention (Adetula, 2013; 2015). Nigeria plays a major role in international politics and has contributed to various peacebuilding and peacekeeping efforts in places such as Sierra Leone, Liberia and the Congo- ECOMOG (Sule 2013). Also, the country ranks as the fifth largest contributor to UN peacekeeping missions (United Nations 2014). Nigeria is the largest oil producer in Africa. Oil 
constitutes 75 per cent of government revenue, but rapid economic growth is frequently found in the non-oil sector (IMF 2013: 8). Its main trading partners include the European Union (EU), the United States, India, Brazil, and China and international business is growing fast. Moreover, the number of Nigerian students studying abroad has expanded due to this increase in international mobility.

Therefore, English language teachers are faced with students who will need to use English predominately in an international context to communicate with speakers from other first languages. Hence it is crucial to know the extent to which there are difficulties in the speech of Nigerian speakers of English when they communicate with other speakers from different linguistic backgrounds.

\section{Methodology}

\section{Materials and Method}

Six speech samples from six audio podcasts (broadcast materials) in which five Nigerian Yoruba speakers delivered speeches were used to determine the levels of intelligibility of Nigerian speakers of English. The choice of all speakers is not intended to be representative of all Nigerian Yoruba speakers; rather, it serves as a reflection of an elite subgroup of the population. Two reasons informed the choice of speakers. The main reason was that regardless of their identity as native Yoruba language speakers, the selected speakers are listened to by a wide audience both nationally and internationally. Thus, all five speakers, irrespective of their profession have a significant role and impact in mass communication and a significant presence on international platforms. Therefore, it is expected that communication for them would encompass international audiences, and so they are expected to be intelligible to a very wide audience. The second factor that determined the selection of these speakers was a consideration of their native language. All of them are Yoruba speakers. Preference was given to the Yoruba language because of its significance and reach. It is one of the three national languages used in Nigeria, and it is also used by a major ethnic group in Nigeria.

The six audio podcasts were presented to 100 international listeners (made up of non-Nigerian speakers from 25 nationalities (See Appendix B)) to transcribe. Two different criteria were used in selecting international listener participants. First, they had to be advanced English users, either undergraduate or graduate, in order to ensure that they had reasonable competence in English. Based on the findings by Eisenstein and Berkowitz (1981) and Matsuura et al. (1999), non-native listeners with low proficiency may not be able to deal with intelligibility (dictation) tests. In order to control the effect of listeners' English proficiency level, all speakers of English from different linguistics backgrounds participating as listeners in this present study 
were required to have 7.0 score in International English Language Testing System (IELTS) or its equivalent, with 7.0 score in Listening, speaking and writing. This was considered to be essential because it ensures that the researcher gets reliable intelligibility test data in this present study. Secondly, listeners were not selected if they had prolonged experience communicating with Nigerian speakers of English. Gass and Varonis (1984) argue that familiarity with a non-native speaker's speech, a particular accent and a particular speaker all influence intelligibility.

Before the listening task, the listeners were informed of the speakers' name, their profession and the situational context that informed the existence of the podcasts. This was done in order to provide the listeners with a framework within which to focus their attention (Atechi, 2004) since it is rare in a real situation to listen to speech or conversation in a complete vacuum (Tiffen, 1974; Osle, 2013). However, the content of the speakers' text was not disclosed to the listeners. The six excerpts were played once to the listeners. The thought of playing the excerpts twice before the listening exercise was considered, but this idea was later dropped because it would have created an unnatural listening situation. In order to keep this as natural as possible, the podcasts (divided units of utterance) were played once.

The listeners heard the utterances in meaningful listening units and provided their responses on white sheets of paper by writing out the utterances in the dictation exercise. They were required to transcribe as precisely as possible what they heard in each of the six excerpts, and they were told to put a dash or a bracket sign where they did not understand, or simply guess what they thought they heard. Listeners transcriptions were used because they present more permanent and easily verifiable records for further study and analysis (Tiffen 1974; Atechi, 2004; Matsuura, Chiba and Ara 2012; Kashiwagi and Snyder, 2010).

After the completion of the listening and dictation exercise, listeners' transcriptions were carefully inputted manually into the computer and checked manually again for accuracy. This enabled the researcher to have personal experience with the data. Various authors have raised a concern about using computer-assisted techniques (Cohen et al., 2011; Flick 2009). One of these concerns includes creating a distance between researchers and data. The listeners' transcriptions were used to locate instances of mismatch between the speakers' recordings and the listeners' transcribed text.

Before discussing the results, this paper will describe the terms and codes used in presenting the data. 


\section{Conventions and Terms Used in Presenting the Data}

\section{Tokens}

A Token represents a word that caused intelligibility breakdown for listeners. For example, consider Extract 2.1

Extract 2.1 (Tokens 17 and 18)

Context: ... a lot of people don't get to know that; I am an introvert ['Intrəvat] person ['pe:s $\left.{ }^{\curvearrowright} n\right] \ldots$ (Speaker four, unit 7-8)

In this extract, the mid-central vowel /3: / in the last syllable of the word "introvert" and the initial syllable of "person" were pronounced as [a] and $\left[\varepsilon^{\prime}\right]$ respectively. This word caused problems with intelligibility for listeners. The two words are separate tokens but represent one type or feature and, in this case, the mid-central vowel /3: /. A single token may sometimes consist of more than one word, particularly when a fixed phrase is involved. Let me illustrate this with an extract from the podcast recordings. In extract 2.2, speaker three has been talking about establishing a business partnership with China. He says:

Extract 2.2

Context: ...we want to be able/to have reasonable revenue from our resources/if you want our resources/we need that our laws and rules must be respected/we want infrastructure/ and if you can give us that/ yes, and we will pay for it either directly/or we will take loan at reasonable interest rate [In' trest' reIt]/ (Speaker three, unit 9-11)

Here interest rate consists of two words, but it is just one entity, so it is treated as a single token of intelligibility breakdown.

\section{Description for Codes used in tabulating the data in this study}

As the data were tabulated (see results throughout for deployment), the following codes were used.

NOL=This code refers to the number of listeners that experienced intelligibility breakdown.

ORP $=($ Orthographic Representation of Phoneme $)$. This signals instances in the data where listeners seemed to have orthographically represented the sound they heard. For example: in Token 17, speaker four pronounced the vowel in "introvert" as the back vowel [a] rather than the mid-central vowel quality [3:] which is expected in the reference accent (Received Pronunciation). Four listeners transcribed the word as "introvat" (phonetically transcribed as ['Introvat]). This transcription shows that the listeners recognised the sound [a] used by the speaker in the final syllable and they orthographically represented this. 
ORA $=($ Orthographic Representation Attempted $)$. This code refers to instances in the data where listeners appeared to have orthographically represented part of a word apart from the syllable in which the pronunciation of a segmental feature varied from the referent accent (RP). For example, "introvert" pronounced as [' Intrəvat] by speaker four was heard as "intro????" by some listeners. This listeners' response shows that part of the word or text (in this case, the first and the second syllable in introvert) has been orthographically represented, but the syllable in which the pronunciation of the speaker has varied from the referent accent (RP) (in this case the final syllable in introvert) is not recognised. Another example that belongs to the code ORA are cases where listeners incorrectly orthographically represented a phoneme used by a speaker. For example, introvert pronounced as ['intrevat] was transcribed as "intellect" (phonetically transcribed as ['Intəlekt]). This transcription demonstrates that the listeners recognised the [e] vowel in the final syllable instead of [a] used by the speaker.

$\mathbf{S A}=$ (Semantically Appropriate). This refers to instances where listeners seemed to have chosen words that make sense in their interpretation of utterances. For example, three listeners transcribed "I am an introvert person" as "I need the right person". This listeners' text or transcription shows that they have chosen words that are meaningful within the utterance but is not contextually appropriate as it does not fit the context in which the utterance was made.

$\mathbf{C A}=($ Contextually Appropriate). This signals instances where listeners seemed to have relied on the context or circumstances in which the utterances were produced or cases where they may have resorted to their own previous background knowledge in their interpretation of utterances. For example, seven listeners transcribed "keep" (pronounced with a short vowel length by speaker one) as "get" in the phrase "... whoever you are, keep your head straight".

$\mathbf{S C}=($ Syntactically Correct $)$. This code refers to cases where listeners seemed to have chosen words that are syntactically correct or appropriate. In other words, they have used their syntactic knowledge to decode the meaning of a word.

$\mathbf{N R}=($ No response). This code refers to instances where listeners did not write anything for the word said by the speaker. For example, I am an introvert (pronounced as ['Intrəvat]) person transcribed as "I am an ?????? person".

\section{Results}

The table provided below presents an overview of each of the vowel quality that was identified, alongside the number of instances of intelligibility breakdown associated with each. 
Table 3.1: Vowels causing intelligibility breakdown

\begin{tabular}{|c|c|c|}
\hline Phonological Factor & Tokens & $\begin{array}{c}\text { Instances of } \\
\text { intelligibility breakdown } \\
\text { to ILs }\end{array}$ \\
\hline \multirow{8}{*}{$\begin{array}{c}\text { Mid-central vowel } \\
\text { [3:] }\end{array}$} & 9 (universalism) & 64 \\
\hline & 11 (early) & 78 \\
\hline & 15 (certain) & 86 \\
\hline & 17 (introvert) & 50 \\
\hline & 3 (work) & 24 \\
\hline & 19 (work) & 29 \\
\hline & 25 (burden) & 42 \\
\hline & 18 (person) & 22 \\
\hline \multirow{9}{*}{$\begin{array}{l}\text { Mid-central vowel } \\
{[ə]}\end{array}$} & 7 (moral) & 24 \\
\hline & 8 (moral) & 32 \\
\hline & 23 (total) & 29 \\
\hline & 24 (critical) & 38 \\
\hline & 12 (revenue) & 43 \\
\hline & 14 (interest rate) & 32 \\
\hline & 15 (certain) & 86 \\
\hline & 20 (deepen) & 36 \\
\hline & $\begin{array}{c}16 \text { (our } \\
\text { commodities) }\end{array}$ & 33 \\
\hline \multirow{10}{*}{$\begin{array}{c}\text { Open-mid central } \\
\text { vowel } \\
{[\Lambda]}\end{array}$} & 1 (other) & 32 \\
\hline & 2 (nothing) & 65 \\
\hline & 4 (must) & 29 \\
\hline & 5 (Sundays) & 30 \\
\hline & 6 (money) & 26 \\
\hline & 10 (among) & 25 \\
\hline & 13 (must be) & 48 \\
\hline & 21 (budgeting) & 43 \\
\hline & 22 (agriculture) & 31 \\
\hline & 26 (buck) & 50 \\
\hline
\end{tabular}

Below, the vowels responsible for intelligibility breakdown shall be discussed in detail.

\subsection{Mid central vowel /3: /}

In Token 3, Speaker one pronounced the vowel quality in "work" as open-mid back vowel [0:] in the phrase "so I work and rest together". The pronunciation of this word caused intelligibility breakdown for 24 listeners. A further breakdown is given in the following table.

\begin{tabular}{|l|l|l|l|l|l|l|l|l|}
\hline & Listener response & NOL & ORP & ORA & SA & CA & SC & NR \\
\hline 1 & $\begin{array}{l}\text { So, I walk } \text { and rest } \\
\text { together }\end{array}$ & 24 listeners & $\checkmark$ & & $\checkmark$ & & $\checkmark$ & \\
\hline
\end{tabular}

The main issue with the pronunciation of "work" here is the use of open-mid vowel [o:]. Precisely the vowel that changes the meaning in the 
minimal pair (In phonology minimal pairs are pairs of words which differ in only one phonological element, such as a phone, phoneme, and have distinct meanings) "work" and "walk". It should be noted that apart from the word work, there were three words in speaker one's speech in which the mid-central vowel quality [3:] could be expected in the reference accent (Received Pronunciation). These words are "versatile", "person", "working" (two occurrences). The extract below shows the wider context in which these words appeared.

Extract 3.1.

Context: ... and I'm supposed to be versatile ['v3:sətail] as an actress. /So, playing Jennifer and playing other roles / has nothing to do with my person ['p3:sən]. Well, I love my job so much / if I'm not resting, I'm working ['w3:kin] / even while working ['w3:kin], I rest. /I'm a producer; I'm a writer. /All my movies, I write them, and I produce them / and I play the lead characters. / So, any spare time I have, I rest. / I work ['wo:k] and rest together...(Speaker one, unit 3-13).

While the speaker pronounced the first syllable of "versatile" and "person" with the mid-central vowel [3:] in the initial syllable, it caused no intelligibility problems for listeners'. However, in the case of "work", there were three instances where the verb form of "work" was used in speaker one's speech (see extract 3.1). On two occasions, the speaker pronounced the first syllable of "working" with the mid-central vowel [3:], and this was completely intelligible to all listeners. However, it was when she pronounced [0:] that intelligibility failure occurred. Jenkins (2000) also drew a similar conclusion. It is interesting to note that speaker one had so much variation in the way she pronounced the mid-central vowel [3:]. It seems she has different lexical sets (a lexical set is a set of words which are pronounced with the same vowel in the reference accents (Wells, 1982)). So "work" belongs in the lexical set with "walk" and "talk", whereas "versatile" and "person" belong in the "nurse" lexical set. Although "work" was in context and listeners had already heard the word twice in speaker one's excerpt, it caused intelligibility problems for 24 listeners.

On the other hand, 76 listeners had no problem understanding the word "work" as they transcribed it correctly. This could be because they relied on the contextual information or circumstances in which the utterances were produced. From the background context, "work" would be an obvious word to have in the utterance rather than "walk" because speaker one in her previous utterances is talking about her job. For these listeners, the context seems to override pronunciation cues (Matsuura, Chiba and Ara, 2012).

This paper has discussed one of the clear cases where the alternative to the mid-central vowel [3:] vowel was the sole cause of intelligibility 
breakdown. Now, it will move to consider one of the complicated tokens where there appears to have been multiple factors that caused the breakdown.

In Token 11, Speaker three pronounced the word "early" ['3: li] as ['aleI] in the phrase "early in the twenty-first century". Here, Speaker three was talking about the period Nigeria established a business partnership with China. He pronounced the first syllable of "early" with a vowel variant [a], a pattern that has been reported in Deterding (2011). In addition to this pronunciation, this speaker used a different vowel length on the first syllable and pronounced the vowel quality on the second syllable with a diphthong [eI]. This pronunciation of "early" as ['aleI] caused intelligibility problems for 78 listeners as exemplified in the following table:

\begin{tabular}{|c|c|c|c|c|c|c|c|c|}
\hline & Listeners' responses & NOL & ORP & $\overline{\text { ORA }}$ & SA & $\mathrm{CA}$ & $\mathrm{SC}$ & NR \\
\hline 1 & I liv $(e d)$ in the $21^{\text {st }}$ century & 25 listeners & $\checkmark$ & & $\checkmark$ & & $\checkmark$ & \\
\hline 2 & I lay in the $21^{\text {st }}$ century & 12 listeners & $\checkmark$ & & & & $\checkmark$ & \\
\hline 3 & I really mean that $21^{\text {st }}$ century & 1 listener & $\checkmark$ & & & & & \\
\hline 4 & I reigned in the $21^{\text {st }}$ century & 2 listeners & $\checkmark$ & & $\checkmark$ & & $\checkmark$ & \\
\hline 5 & I let him be in the $21^{\text {st }}$ century & 4 listeners & $\checkmark$ & & & & & \\
\hline 6 & $\begin{array}{l}\text { I led in the twenty-first } \\
\text { century }\end{array}$ & 2 listeners & $\checkmark$ & & & & $\checkmark$ & \\
\hline 7 & ???? in the $21^{\text {st }}$ century & 18 listeners & & & & & & $\checkmark$ \\
\hline 8 & I ???? in the $21^{\text {st }}$ century & 14 listeners & & & & & & $\checkmark$ \\
\hline
\end{tabular}

As shown in the listeners' transcriptions above, all those who misunderstood the word "early" recognised the first syllable as "I" [aI] in "early". The word "I" has [a] as the first part of the initial diphthong which suggests that the listeners have heard the pronunciation of open front vowel [a] in the initial syllable of "early". This may explain why 60 listeners transcribed "I" in "I lived", "I lay", "I let", "I led", "I reigned", and "I really". In addition to problems with the mid-central vowel, the vowel quality in the second syllable may be a contributory factor to the intelligibility breakdown. For instance, 12 listeners wrote "I lay" in place of "early". This response is the exact match of the speakers' pronunciation, and it reveals that they have orthographically represented the two sounds [a] (in the first syllable) and [er] (in the second syllable) used by the speaker.

There are many semantic cues available to the listeners that could aid the intelligibility of the word. But it seems the listeners have relied mainly on pronunciation cues. The words they have suggested to fill the slot do not fit the context of the word. Sometimes, it appears the listeners have used their syntactic knowledge to help decipher the word they heard even when it does not make sense. 
32 listeners did not write anything for the word as indicated by the question marks on their sheet. Of the 32 listeners, 14 wrote "I????". It is quite possible that these listeners heard [a] but since they cannot relate what they heard to "early", they left the word and put question marks symbols to indicate that they have a problem. This is just a speculation. The remaining 18 listeners did not respond to the word. It is difficult to conclude on which of the two features of pronunciation caused the problems for these 18 listeners (Deterding and Mohamad, 2016; Deterding, 2014).

Could the first vowel be responsible, or could it be because of the diphthongal pronunciation in the second syllable or a combination of the two? The observation from the listeners' transcription is that listeners who perceived and recognised the variant [a] are greater in number than those unable to write something down. In sum, the findings suggest that patterns of the mid-central vowel [3:] are a major contributory factor for the problem in this case (Deterding and Mohamad, 2016; Deterding, 2010; 2011; Jenkins, 2002) though this study cannot ignore the contribution of the second syllable issue.

The following section is a consideration of another central vowel responsible for intelligibility breakdown when international listeners listened to Nigerian speakers.

\subsection{Mid Central Vowel /a/ (Schwa)}

In Token 7 and 8, speaker two pronounced the word "moral" / mprəl/ as ['mbra] and this caused intelligibility failure for listeners. Before analysing these two tokens in more detail, the wider context in which they occurred is given in the context below:

\section{Extract 3.2}

Context: I find the very notion of political correctness/ very condescending. /hmm it's an assumption of a kind of hmm hmm/ standing on high moral ['mpra] grounds/ and hmm presuming that others cannot quite attain/ that moral ['mpra] height or even cultural universalism... (Speaker two, unit 1-6)

In the first occurrence of "moral", speaker two pronounced moral ['mprol] as ['mora] in the phrase "standing on high moral grounds..." (Speaker two unit 4). There are two segmental issues here and this paper will consider them in turn. First of all, the vowel of the second syllable (/// for the reference accent) was pronounced as vowel variant [a]. In addition to this, a pronunciation variant lacking the dark [1] was used in the coda of the same syllable. This distinct pronunciation led to 24 instances of unintelligibility with listeners who responded as follows: 


\begin{tabular}{|l|l|l|l|l|l|l|l|l|}
\hline & Listeners' responses & NOL & ORP & ORA & SA & CA & SC & NR \\
\hline 1 & standing on high more grounds & 9 listeners & $\checkmark$ & & & & & \\
\hline 2 & standing on high ????? grounds & 15 listeners & & & & & & $\checkmark$ \\
\hline
\end{tabular}

As shown above, 9 listeners wrote more which suggests that they identified the first syllable but did not recognise the second syllable. This response seems to suggest that the problem is in the second syllable. 15 listeners did not write anything for the word which may demonstrate that they could not relate what they heard to the context in which the word was produced.

As Speaker two proceeded with his speech, he repeated the word moral /' mprəl/ as [' mpra] (see Extract 3.2) with the use of [a] in the second syllable and the non-use of [1] in the same syllable. This pronunciation led to 32 instances of unintelligibility with listeners. Below are the listeners' interpretations of the word.

\begin{tabular}{|l|l|l|l|l|l|l|l|l|}
\hline & Listeners' responses & NOL & ORP & ORA & SA & CA & SC & NR \\
\hline 1 & that ?????? height & 17 listeners & & & & & & $\checkmark$ \\
\hline 2 & that more height & 11 listeners & $\checkmark$ & & & & & \\
\hline 3 & that moor height & 4 listeners & $\checkmark$ & & & & & \\
\hline
\end{tabular}

In (1) of the transcriptions above, 17 listeners failed to respond as they did not write anything for the word "moral". It is difficult to say what the problem is for these 17 listeners as they did not respond. However, what can be inferred from those that misidentified "moral" is that they perceived the first syllable but did not recognise the final syllable, which suggests the issue is in the final syllable. For example, in example (2) and (3), 11 listeners heard moral as "more" and four listeners as "moor". These responses imply that the listeners recognised the first syllable but did not identify the second syllable probably because of the full vowel [a] in the ultimate syllable and the nonrealisation of dark [1].

Before leaving, mid-central vowel [ə], this paper will look at Token 15 (See Table 3.1) where [ə] was pronounced with a short lax vowel [I].

In Token 15, speaker three pronounced certain ['s3:tən] as ['satın] with the variant [a] in the first syllable and the vowel variant [I] in the second syllable. This pronunciation caused intelligibility failure for listeners. Before analysing this token in detail, the wider context in which it occurred is given below.

Extract 3.3

Context:What does China want from us? /China wants certain ['satın] of our commodities/ to enhance their own development and keep it going/ (Speaker three, unit 23-25). 
The word "certain" (pronounced ['satın]) caused intelligibility breakdown for 86 listeners. The examples below give listeners transcriptions of the word:

\begin{tabular}{|l|l|l|l|l|l|l|l|l|}
\hline & Listeners' responses & NOL & ORP & ORA & SA & CA & SC & NR \\
\hline 1 & $\begin{array}{l}\text { China wants acting of our } \\
\text { commodities }\end{array}$ & 15 listeners & $\checkmark$ & & & & & \\
\hline 2 & $\begin{array}{l}\text { China wants act in of our } \\
\text { commodities }\end{array}$ & 11 listeners & $\checkmark$ & & & & & \\
\hline 3 & $\begin{array}{l}\text { China was access to our } \\
\text { commodities }\end{array}$ & 1 listener & $\checkmark$ & & $\checkmark$ & & $\checkmark$ & \\
\hline 4 & $\begin{array}{l}\text { China wants fracting of our } \\
\text { commodities }\end{array}$ & 4 listeners & $\checkmark$ & & & & & \\
\hline 5 & $\begin{array}{l}\text { China wants half } \text { of our } \\
\text { accomodities }\end{array}$ & 1 listener & $\checkmark$ & & $\checkmark$ & $\checkmark$ & $\checkmark$ & \\
\hline 6 & $\begin{array}{l}\text { China wants something of our } \\
\text { commodities }\end{array}$ & 9 listeners & $\checkmark$ & & $\checkmark$ & & $\checkmark$ & \\
\hline 7 & $\begin{array}{l}\text { China wants satin of our } \\
\text { commodities }\end{array}$ & 3 listeners & $\checkmark$ & & & & & \\
\hline 8 & $\begin{array}{l}\text { China wants??????? of (our } \\
\text { commodities) }\end{array}$ & 36 listeners & & & & & & $\checkmark$ \\
\hline 9 & China wants?????? our economy & 6 listeners & & & & & & $\checkmark$ \\
\hline
\end{tabular}

In this token, apart from the alternative to [3:] in the first syllable which seems to be the main cause of intelligibility breakdown, the quality of vowel [I] used by the speaker in the second syllable may be a contributory factor to this intelligibility breakdown. This is because 42 out of those who misunderstood the word certain perceived [I] in the final syllable of "certain" as seen in examples such as "fracting", "satin", "something", "acting" and "act in".

The next section looks at the intelligibility breakdown arising because of a distinct pronunciation of the referent sound $/ \Lambda /$.

\subsection{Open-mid Central Vowel / $/ /$}

In Token 2, Speaker one (a Nigerian actress) is talking about the role she played in her recent movie. She pronounced the vowel in the first syllable of "nothing" as [0] where the reference accent would use $[\Lambda]$. Along with this pronunciation, the onset of the second syllable was produced with an alveolar plosive [t], while the coda of the same syllable was pronounced with an alveolar nasal [n]. So, she said ['notin] in the phrase "... has nothing to do with my person". The wider context for the word is shown in extract 3.4.

\section{Extract 3.4}

Context: I am not worried because I'm an actress, / I should be able to play any role/and am supposed to be versatile as an actress/so playing Jennifer and playing other roles/has nothing ['notın] to do with my person... (Speaker one, unit 1-5) 
The pronunciation of the word "nothing" as ['notin] caused intelligibility breakdown for 65 listeners. This was one of the major intelligibility breakdowns where ['notın] was abandoned as they did not transcribe the word. A number of explanations seem plausible for the cause of the breakdown. Could it be the vowel quality used on the first syllable or the consonants used in the second syllable?

The analysis suggests that the use of [0] was the cause of intelligibility breakdown in this case while the use of alveolar plosive [t] for dental fricative $[\theta]$ and alveolar nasal $[\mathrm{n}]$ for velar [ $\mathrm{n}]$ seems not to have been an issue for respondents. Three sets of findings support the argument. (1) The word "nothing" occurred in speaker four's speech and was pronounced as ['n^tIn] (with alveolar plosive [t] and alveolar nasal [n]) in "so that nothing gets missing in it". But this did not cause intelligibility problems for listeners as they all found the word intelligible. (2) All the time the Nigerian speakers in my study used an alveolar nasal [n] for velar [n] in "things", "everything", "something", "going", "missing", "housing", "getting", these variations did not hamper their intelligibility. This finding contrasts with Jenkins (2000), who included velar nasal [ $\mathrm{y}$ ] as part of the features that are critical for maintaining intelligibility in her Lingua Franca Core. (3) The Nigerian speakers in my study most of the time pronounced the voiced dental fricative $[\theta]$ with an alveolar plosive [ $t]$. This could be because the Yoruba language (the speakers' L1) and most Nigerian languages lack the dental fricative $/ \theta /$ (Jibril, 1982; Simo Bobda, 1995; 2007; Adetugbo, 2009). For example, "things" was realised as [tins], "everything" as ['evritm], "somethings" as ['s $\Lambda$ mtInz], "thought" as [to:t], "think" as [tInk], and "growth" as [grəot]).

But these usages did not hamper intelligibility in my study. This result echoes the research result of Deterding (2013) and Jenkins (2000; 2006). The reason why this intelligibility was not affected can partly be explained by the fact that in reality, some native speakers also do not use these sounds $/ \theta \partial /$, as many in London use [f, v] instead (Wells, 1982: 328) while some in Ireland and New York City use [t, d] (or dental stops) (Wells, 1982: $429,515)$. When dental fricatives are "replaced", a wide range of sounds may occur instead. Not only are [f, v] used by some native speakers and $[t, d]$ by others, but [f, v] are also used by speakers from Hong Kong (Hung, 2000), [t, d] occur throughout Association of South East Asian Nations (ASEAN) (Deterding and Kirkpatrick, 2006), African English (Atechi 2004), and [s, z] may also occur with speakers of English from many different countries including Germany (Swan, 1987) and China (Chang, 1987; Ho, 2003). So, in token 2, it is highly likely that this breakdown arises from the use of an openmid back vowel [0] on the first syllable and not the use of variant [t] and an alveolar nasal [n]. 
In Token 26, Speaker six is talking about a newly formed Nigerian political party, which he launched to provide a platform for people of flawless character who have withdrawn from the Nigerian political arena due to corruption. In his speech, he called on people of like minds to register as members of the party that will provide an alternative for what he described as a corrupt and morally bankrupt system. He says:

Extract 3.5

Context: /... there are many voiceless people in Nigeria/ and sometimes even when they have a voice, / when they have a platform/for the expression of their voice, /they find they cannot really relate/ to any of the existing political parties. /this is especially so /of a very idealistic youth / $\mathrm{hmm}$ who feel that there is no point trying to buck [bok] the system" ... / (Speaker six, unit 15-19).

Here, the speaker pronounced the idiom "buck the system" as [bok ðə 'sis təm]. It can be observed that in this phrase, the vowel in the word "buck" is pronounced with an open back vowel [p]. This pronunciation may have caused intelligibility breakdown for 50 listeners who responded as follows:

\begin{tabular}{|c|l|l|l|l|l|l|l|l|}
\hline & Listeners' responses & NOL & ORP & ORA & SA & CA & SC & NR \\
\hline 1 & $\begin{array}{l}\text { who feel that there is no point trying } \\
\text { to??? the system }\end{array}$ & 15 listeners & & & & & & $\checkmark$ \\
\hline 2 & $\begin{array}{l}\text { who feel that there is no point trying to } \\
\text { back the system }\end{array}$ & 17 listeners & $\checkmark$ & & $\checkmark$ & & $\checkmark$ & \\
\hline 3 & $\begin{array}{l}\text { who feel that there is no point trying to } \\
\text { block the system }\end{array}$ & 5 listeners & $\checkmark$ & & $\checkmark$ & & $\checkmark$ & \\
\hline 4 & $\begin{array}{l}\text { who feel that there is no point to bock } \\
\text { the system }\end{array}$ & 10 listeners & $\checkmark$ & & & & & \\
\hline 5 & $\begin{array}{l}\text { who feel that no point to bog the } \\
\text { system }\end{array}$ & 1 listener & $\checkmark$ & & & & & \\
\hline 6 & $\begin{array}{l}\text { who feel that there is no point to beg } \\
\text { boke the system }\end{array}$ & 1 listener & $\checkmark$ & & & & & \\
\hline 7 & $\begin{array}{l}\text { who feel that there is no point to } b o p \\
\text { the system }\end{array}$ & 1 listener & $\checkmark$ & & & & & \\
\hline
\end{tabular}

As shown in the transcriptions above, 15 listeners did not write down anything for the word, suggesting that they did not understand the pronunciation of the word. 17 listeners were unable to identify the word buck hearing it as "back" which suggests that they heard the vowel quality in buck as a front vowel [æ]. Five listeners heard buck as "block" ['blpk] which suggests that these listeners recognised some of the phonetic cues they heard and made a guess that seems to fit the context. Ten listeners heard buck as "bock" which demonstrates that their attention was primarily focused on the pronunciation of [p] and this probably is the main issue that caused intelligibility breakdown. The remaining three listeners wrote "bog", "boke" 
and "bop" respectively which suggest the vowel quality used by the speaker is the cause of intelligibility breakdown. Overall, the fact that all the listeners who failed to understand or who misunderstood buck were confused by the vowel quality led to the conclusion that the use of [p] was the major cause of unintelligibility. It is also possible that the use of the idiomatic phrase to buck the system (this phrase is defined by Cambridge Dictionary as "to fight against the usual way of doing something") is not familiar to listeners. This may have contributed to these listeners being unable to guess the target word correctly.

\section{Summary of Results}

As discussed above, the findings indicate that the alternatives to central vowels [3:], [ə] and [ $\Lambda$ ] seems to be an issue for international listeners (nonNigerian speakers of English). There were eight tokens of intelligibility breakdown when a vowel variant was used where many users of English would use the mid-central vowel [3:]; ten tokens when a distinct pronunciation was used where users of English would use $[\Lambda]$ and nine tokens when a variant was used where many speakers of English would use [ə] (see Table 3.1).

\section{Pedagogical Implications}

Looking at the results of this study, it is clear that some features of the pronunciation of English by speakers from Nigeria are more important for international intelligibility than others. Specifically, the central vowels [3:], $[\Lambda]$, and [ə] are features of pronunciation English teachers in Nigeria should work on in their teaching; but there is less need to pay attention to dental fricatives $/ \theta /, / \delta /$, and velar nasal [ $\mathrm{\eta}]$. For example, in this study, the use of alveolar plosives [t], [d] for dental fricatives $/ \theta /, / \delta /$ occurred 20 times and the realisation of velar nasal $[\mathrm{n}]$ as alveolar nasal [n] appeared 15 times (Banjo, 1971; Jibril, 1982; 1986; Simo Bobda, 1995; 2007; Udofot, 2007). But these variations did not cause phonological unintelligibility on a single occasion. This illustrates one point that there is no need always to use RP or "imitate" the pronunciation of the "ideal native speaker".

\section{Limitations}

The present study focused on the intelligibility of English spoken by educated Nigerian speakers', with a special focus on 100 international listeners. Thus, the findings of this research might not be applicable to all Nigerian English speakers, and to non-Nigerian speakers at different proficiency levels. Future studies may generate new insights and extend current knowledge by replicating this study with different groups of speakers and listeners.7. 


\section{Conclusion}

The current research has indicated a rich and fascinating vein of work required to contribute to current knowledge and understanding of English intelligibility in the Nigerian context. Specifically, the research has added greatly to the understanding of the segmental features of pronunciation that hamper the intelligibility of Nigerian speakers when they communicate both in international and intranational contexts. As discussed, this understanding forms a useful foundation for reconsidering how English pronunciation is taught in Nigerian schools.

\section{References:}

1. Adetugbo, A. (2009) Problems of standardization and Nigerian English phonology. In: Dadzie, K. \& Awonusi, S. (eds.) Nigerian English: Influences and Characteristics. Lagos: Concept Publications. pp.179-199.

2. Adetula, V.A. (2013) Nigeria's Rebased Economy and its Role in Regional and Global Politics. Available at: http://www.eir.info/2014/10/13/nigerias-rebased-economy-and-its-role-inregional-and-global-politics/(Accessed: March 11 2014).

3. Atechi, S.N. (2004) The Intelligibility of Native and Non-Native English Speech: A Comparative Analysis of Cameroon English and American and British English. University of Chemnitz. Available at: http://d-nb.info/972345264/34 .

4. Bamgbose, A. (1971) The English language in Nigeria. The English Language in West Africa. London: Longman. 35 pp.48.

5. Cohen, L. L. Manion, and K. Morrison, (2011) Research Methods in Education, $7^{\text {th }}$ edition, USA and Canada: Routledge (first published: 1988)

6. Crystal, D. (1997) English as a Global Language. Cambridge: Cambridge University Press.

7. Crystal, D. (2003a) English as a global language, $2^{\text {nd }}$ ed. Cambridge: Cambridge University Press.

8. Deterding, D. (2005) Listening to estuary English in Singapore. TESOL Quarterly. 39(3) pp.425-440.

9. Deterding, D. (2011) English language teaching and the lingua franca core in east Asia. In: Proceedings of the International Conference of Phonetic Sciences. pp.92-95.

10. Deterding, D. (2013) Misunderstandings in English as a Lingua Franca: An Analysis of ELF Interactions in South-East Asia. Berlin: De Gruyter Mouton.

11. Deterding, D. \& Kirkpatrick, A. (2006) Emerging South-East Asian Englishes and intelligibility. World Englishes. 25(3-4) pp.391-409. 
12. Deterding, D. \& Mohamad, N.R. (2016) The role of vowel quality in ELF misunderstandings. Journal of English as a Lingua Franca. 5(2) pp.291-307.

13. Eisenstein, M. \& Berkowitz, D. (1981) The effect of phonological variation on adult learner comprehension. Studies in Second Language Acquisition. 4(1) pp.75-80.

14. Flick, U. (2009) The Sage Qualitative Research Kit: Collection. SAGE Publications Limited.

15. Gass, S. \& Varonis, E.M. (1984) The effect of familiarity on the comprehensibility of non-native speech. Language Learning. 34(1) pp.65-87.

16. Jenkins, J. (2000) The Phonology of English as an International Language. Oxford: Oxford University Press.

17. Jenkins, J. (2003) World Englishes: A Resource Bookfor Students, $2^{\text {nd }}$ ed. London: Routledge.

18. Jenkins, J. (2006) Current perspectives on teaching world Englishes and English as a lingua franca. Tesol Quarterly. 40(1) pp.157-181.

19. Jenkins, J. (2007) English as a lingua franca: Attitude and identity. Oxford: Oxford University Press.

20. Jibril, M.M. (1982) Phonological Variation in Nigerian English. Unpublished $\mathrm{PhD}$ thesis, University of Lancaster

21. Kachru, B. (1986) The Alchemy of English: The Spread, Functions and Models of Non-Native Englishes. Oxford: Pergamon Press.

22. Kachru, Y. (2005) Teaching and learning of world Englishes. In: Hinkel, E. (ed.) Handbook of Research in Second Language Teaching and Learning. Mahwah, NJ: Lawrence Erlbaum Associates. pp.155173.

23. Kachru, B.B. \& Nelson, C.L. (1996) World Englishes. In: McKay, S.L. \& Hornberger, N.H (ed.) Sociolinguistics and Language Teaching. Cambridge: Cambridge University Press. pp.71-102.

24. Kashiwagi, A. \& Snyder, M. (2010) Speech characteristics of Japanese speakers affecting American and Japanese listener evaluations. Teachers College, Columbia University Working Papers in TESOL \& Applied Linguistics. 10(1) pp.1-14.

25. Kirkpatrick, A. (2007) The communicative strategies of ASEAN speakers of English as a lingua franca. English in Southeast Asia: Varieties, Literacies and Literatures. 118135.

26. Kirkpatrick, A., Deterding, D. \& Wong, J. (2008) The international intelligibility of Hong Kong English. World Englishes. 27(3-4) pp.359-377. 
27. Matsuura, H., Chiba, R. \& Fujieda, M. (1999) Intelligibility and comprehensibility of american andIrish englishes in japan. World Englishes. 18(1) pp.49-62.

28. Matsuura, Reiko and Satoshi (2012) International intelligibility of learner English.

29. McArthur, T. (2002) The Oxford Guide to World English. Oxford: Oxford University Press Oxford.

30. Nero, S. (2006) Language, identity, and education of Caribbean English speakers. World Englishes. 25(3-4) pp.501-511.

31. Odumuh, A.E. (1987) Nigerian English (NigE). Zaria: Ahmadu Bello University Press.

32. Osle Ezquerra, Á. (2013) The Speech Intelligibility of English Learners of Spanish at Key Stage 4. Unpublished PhD thesis, Queen Mary University.

33. Quirk, R. (1990) Language varieties and standard language. English Today. 6(1) pp.3-10.

34. Rubdy, R. \& Saraceni, M. (2006) English in the World: Global Rules, Global Roles. London \& New York: Continuum.

35. Saraceni, M. (2015) World Englishes: A Critical Analysis. Bloomsbury Publishing.

36. Simo Bobda, A. (1995) The phonologies of Nigerian English and Cameroon English. New Englishes: A West African Perspective. pp.248-268.

37. Simo Bobda, A.S. (2007) Some segmental rules of Nigerian English phonology. English World-Wide. 28(3) pp.279-310.

38. Tiffen, B.W. (1974) The Intelligibility of Nigerian English. Unpublished PhD thesis, University of London.

39. Trudgill, P. (1998) John honey. language is power: The story of standard English and its enemies. Journal of Sociolinguistics. 2pp.457-460.

40. Udofot, I. (2004) Varieties of spoken Nigerian English. The Domestication of English Language in Nigeria: A Festschrift in Honour of Abiodun Adetugbo. pp.93-113.

41. Udofot, I. (2007) A tonal analysis of standard Nigerian English. Journal of the Nigerian English Studies Association. 3(1) pp.58-68.

42. Wells, J.C. (1982) Accents of English. Cambridge: Cambridge University Press.

43. Widdowson, H.G. (1994) The ownership of English. TESOL Quarterly. 28(2) pp.377-389. 